\title{
Role of TAAR1 within the Subregions of the Mesocorticolimbic Dopaminergic System in Cocaine-Seeking Behavior
}

\author{
미ian-Feng Liu, ${ }^{1}$ ㅇ Justin N. Siemian, ${ }^{1}$ Robert Seaman, $\mathrm{Jr},{ }^{1}$ Yanan Zhang, ${ }^{2}$ and $\odot \mathrm{Jun}-\mathrm{Xu} \mathrm{Li}{ }^{1}$ \\ ${ }^{1}$ Department of Pharmacology and Toxicology, University at Buffalo, Buffalo, New York 14214, and ${ }^{2}$ Research Triangle Institute, Research Triangle Park, \\ North Carolina 27709
}

A novel G-protein coupled receptor, trace amine-associated receptor 1 (TAAR1), has been shown to be a promising target to prevent stimulant relapse. Our recent studies showed that systemic administration of TAAR1 agonists decreased abuse-related behaviors of cocaine. However, the role of TAAR1 in specific subregions of the reward system in drug addiction is unknown. Here, using a local pharmacological activation method, we assessed the role of TAAR1 within the subregions of the mesocorticolimbic system: that is, the VTA, the prelimbic cortex (PrL), and infralimbic cortex of medial prefrontal cortex, the core and shell of NAc, BLA, and CeA, on cue- and drug-induced cocaine-seeking in the rat cocaine reinstatement model. We first showed that TAAR1 mRNA was expressed throughout these brain regions. Rats underwent cocaine self-administration, followed by extinction training. R05166017 (1.5 or $5.0 \mu \mathrm{g} / \mathrm{side})$ or vehicle was microinjected into each brain region immediately before cue- and drug-induced reinstatement of cocaine-seeking. The results showed that microinjection of R05166017 into the VTA and PrL decreased both cue- and drug priming-induced cocaine-seeking. Microinjection of R05166017 into the NAc core and shell inhibited cue- and drug-induced cocaine-seeking, respectively. Locomotor activity or food reinforced operant responding was unaffected by microinjection of R05166017 into these brain regions. Cocaine-seeking behaviors were not affected by R05166017 when microinjected into the substantia nigra, infralimbic cortex, BLA, and CeA. Together, these results indicate that TAAR1 in different subregions of the mesocorticolimbic system distinctly contributes to cue- and druginduced reinstatement of cocaine-seeking behavior.

Key words: cocaine; mesocorticolimbic regions; reinstatement; self-administration; TAAR1

Significance Statement

TAAR1 has been indicated as a modulator of the dopaminergic system. Previous research showed that systemic administration of TAAR1 agonists could attenuate cocaine-related behaviors, suggesting that TAAR1 may be a promising drug target for the treatment of cocaine addiction. However, the specific role of TAAR1 in subregions of the mesocorticolimbic system in drug addiction is unknown. Here, we first showed that TAAR1 mRNA is expressed throughout the subregions of the mesocorticolimbic system. Then, by using a local pharmacological activation method, we demonstrated that TAAR1 in different subregions of the mesocorticolimbic system distinctly contributes to cue- and drug-induced reinstatement of cocaine-seeking behavior.

\section{Introduction}

Cocaine addiction is a psychiatric disorder characterized by compulsive drug-seeking and drug-taking. Although mechanisms

\footnotetext{
Received June 23, 2016; revised Nov. 29, 2016; accepted Dec. 10, 2016.

Author contributions: J.-F.L. and J.-X.L. designed research; J.-F.L., J.N.S., and R.S. performed research; Y.Z. contributed unpublished reagents/analytic tools; J.-F.L. and J.-X.L. analyzed data; J.-F.L. and J.-X.L. wrote the paper.

This work was supported by the National Institutes of Health, National Institute on Drug Abuse Grants R01DA034806 and R21DA040777. The content is solely the responsibility of the authors and does not necessarily represent the official views of the National Institutes of Health.

The authors declare no competing financial interests.

Correspondence should be addressed to Dr. Jun-Xu Li, Department of Pharmacology and Toxicology, University at Buffalo, State University of New York, 102 Farber Hall, 3435 Main Street, Buffalo, NY 14214. E-mail: junxuli@buffalo.edu.
}

underlying cocaine addiction have been extensively investigated, effective treatment for cocaine addiction remains unavailable. Relapse to addictive drugs can occur even after long-term abstinence, and the prevention of relapse has been a critical challenge for addiction treatment (Kauer and Malenka, 2007; Venniro et al., 2016). Recently, it was demonstrated that partial and full agonists of a G-protein-coupled receptor, trace amine-associated receptor 1 (TAAR1), attenuated cocaine-related behaviors and prevented reinstatement of cocaine-seeking behavior, providing

D0I:10.1523/JNEUROSCI.2006-16.2016

Copyright $\odot 2017$ the authors $\quad 0270-6474 / 17 / 370882-11 \$ 15.00 / 0$ 
a promising therapeutic target for cocaine addiction (Pei et al., 2014, 2016; Thorn et al., 2014; Jing and Li, 2015).

The endogenous ligands of TAAR1 are a group of amines expressed at low concentrations, named as trace amines, which are structurally related to the classical monoamine neurotransmitters (Burchett and Hicks, 2006; Grandy, 2007; Xie and Miller, 2007). TAAR1 has been implicated as a modulator of the dopaminergic system (Xie and Miller, 2007, 2009a). TAAR1 knock-out mice showed augmented amphetamine-induced striatal release of dopamine (DA) (Lindemann et al., 2008). Moreover, transgenic mice that overexpress TAAR1 specifically in the brain showed decreased sensitivity to amphetamine (Revel et al., 2012a). Systemic administration of selective TAAR1 agonists dose-dependently suppressed stimulant-induced hyperlocomotion and the firing frequency of dopaminergic neurons in the VTA, suggesting a critical role of TAAR1 in modulating DArelated behaviors (Revel et al., 2011; Thorn et al., 2014).

The dopaminergic neurons in the VTA and the substantia nigra (SN) project to limbic and cortical areas, including the dorsal and ventral striatum, the frontal cortex, and the amygdala (Carpenter and Peter, 1972; Hattori et al., 1973; Chronister et al., 1980; Oades and Halliday, 1987). The dopaminergic and glutamatergic projections within these brain regions play critical roles in the reinstatement of cocaine-seeking (Kalivas and McFarland, 2003; Schmidt et al., 2005). TAAR1 mRNA and protein are expressed throughout the aforementioned brain regions (Grandy, 2007). In vitro evidence demonstrated an interaction between TAAR1 and DA transporter (DAT), suggesting that the inhibitory effects of TAAR1 on psychostimulants might be mediated by DAT (Xie and Miller, 2007, 2009b). However, other studies showed that TAAR1 agonists attenuated hyperlocomotion in $\mathrm{DAT}^{-1-}$ mice, indicating that the effects of TAAR1 agonists may be DAT-independent (Revel et al., 2011, 2012b). TAAR1 may also interact with presynaptic D2 autoreceptors to negatively regulate the release of DA in the nucleus accumbens (NAc) (Xie et al., 2007; Leo et al., 2014). In addition, a recent study showed that TAAR1 regulated the number/efficiency of the NMDAR in TAAR1 knock-out neurons in the MPFC in mice (Espinoza et al., 2015b). Combined, these results indicate that the role of TAAR1 in distinct brain regions might be mediated by different cellular mechanisms. Although systemic modulation of TAAR1 activity by genetic strategies and pharmacological reagents regulates addictive drug-related behaviors, the specific role of TAAR1 in subregions of the mesocorticolimbic system in drug addiction is still unknown.

One of the most widely used models to study relapse to cocaine is the reinstatement model (Bossert et al., 2013). Reinstatement of drug-seeking refers to reemergence of a previously acquired drugseeking behavior by drug-paired cues, noncontingent priming injections of drug, or stressors after extinction (de Wit and Stewart, 1981; Shaham et al., 2003). Here, we examined the role of TAAR1 in different brain regions of the mesocorticolimbic system in mediating the reinstatement of cocaine-seeking behavior. We first tested the expression of TAAR1 mRNA in several subregions of the mesocorticolimbic system, including the VTA, SN, core and shell subregions of NAc, prelimbic (PrL) and infralimbic (IL) subregions of mPFC, basolateral amygdala (BLA), and central amygdala (CeA) to examine whether there were differences between these brain regions. We then tested the effects of microinjection of a TAAR1 full agonist RO5166017 ((S)-4-[(ethyl-phenyl-amino)-methyl]-4,5-dihydrooxazol-2-ylamine) into these brain regions on cue- and druginduced reinstatement of cocaine-seeking behavior.

\section{Materials and Methods}

Subjects. Adult male Sprague Dawley rats (initial weight 250-280 g; Envigo, RRID: RGD_70508) were housed individually on a 12/12 h light/ dark cycle (behavioral experiments were conducted during the light period) with free access to water and food, except during experimental sessions. Rats were maintained and experimental procedures were approved by the Institutional Animal Care and Use Committee, University at Buffalo, the State University of New York, and with the 2011 Guide for the care and use of laboratory animals (Institute of Laboratory Animal Resources on Life Sciences, National Research Council, National Academy of Sciences, Washington, DC).

Drugs. Drugs used in this study included cocaine hydrochloride (Research Technology Branch, National Institute of Drug Abuse, Rockville, MD) and RO5166017 (synthesized at Research Triangle Institute, purity $>98 \%$ ). Cocaine hydrochloride was dissolved in $0.9 \%$ physiological saline. RO5166017 was dissolved in vehicle, which contains 1 part absolute ethanol, 1 part Emulphor-620 (Rhodia), and 18 parts physiologic saline (Liu et al., 2016).

$R N A$ extraction and $q R T-P C R$. Tissue punches from specific brain regions of Naive rats were collected and immediately stored at $-80^{\circ} \mathrm{C}$. RNA was isolated and purified from these samples using Trizol (Invitrogen; Thermo Fisher Scientific) and the RNeasy Micro Kit (QIAGEN) with a DNase step. RNA concentration was measured on a Nanodrop spectrophotometer (ND-100; Thermo Fisher Scientific) and $500 \mathrm{ng}$ cDNA was then synthesized using an iScript cDNA synthesis kit (Bio-Rad Laboratories). Taar1 mRNA expression was measured using qRT-PCR with IQ SYBR Green Supermix (Bio-Rad Laboratories). Primer sets used for amplification are as follows: TAAR1, forward: $5^{\prime}$-GTCAAGGGAT GTCCGTGCTT-3'， reverse: 5'-CCAATTTGTGGGCGTGTGAA-3'; GAPDH, forward: 5'-AACGACCCCTTCATTGAC-3', reverse: 5' TCCACGACATACTCAGCA-3'. The products of TAAR1 and GAPDH are 127 and $191 \mathrm{bp}$, respectively. Quantification of mRNA was conducted using an iQ5 system (Bio-Rad Laboratories). Reactions were run in triplicate and analyzed using the $\Delta \Delta$ CT method as described previously using GAPDH as a housekeeping gene (Gancarz et al., 2015).

Surgeries and intracranial injections. The rats (weighing 280-300 g when surgery began) were anesthetized with ketamine and xylazine (75 and $5 \mathrm{mg} / \mathrm{kg}$, respectively, i.p.). Rats were first implanted with chronic indwelling jugular catheters as previously described (Thorn et al., 2014). Three days after catheterization surgery, rats received stereotaxic surgery. Guide cannulae (23 gauge; Plastics One) were bilaterally implanted $1 \mathrm{~mm}$ above the specific brain regions (Chai et al., 2014; Liu et al., 2015; Thorn et al., 2016). The coordinates for brain regions were the following: PrL [angle, $10^{\circ}$; anterior/posterior (AP), $3.0 \mathrm{~mm}$; medial/lateral (ML), \pm 1.6 $\mathrm{mm}$; dorsal/ventral (DV), $-4.0 \mathrm{~mm}$ ]; IL (angle, $10^{\circ}$; AP, $3.0 \mathrm{~mm}$; ML, $\pm 1.6 \mathrm{~mm}$; DV , $-5.0 \mathrm{~mm}$ ); NAc shell (angle, $10^{\circ}$; AP, $1.8 \mathrm{~mm}$; ML, \pm 2.1 $\mathrm{mm}$; DV , $-7.3 \mathrm{~mm}$ ); NAc core (angle, $16^{\circ}$; AP, $1.8 \mathrm{~mm}$; ML, $\pm 3.2 \mathrm{~mm}$; $\mathrm{DV},-7.3 \mathrm{~mm})$; BLA (AP, $-2.9 \mathrm{~mm}$; ML, $\pm 5.0 \mathrm{~mm}$; DV, $-8.5 \mathrm{~mm}$ ); $\mathrm{CeA}$ (AP, $-2.9 \mathrm{~mm}$; ML, $\pm 4.2 \mathrm{~mm}$; DV,$-7.8 \mathrm{~mm}$ ); VTA (angle, $10^{\circ}$; AP, $-5.2 \mathrm{~mm}$; ML, $\pm 1.8 \mathrm{~mm}$; DV,$-8.5 \mathrm{~mm}$ ); SN (AP, $-5.2 \mathrm{~mm}$; ML, \pm 2.8 $\mathrm{mm}$; DV, $-8.5 \mathrm{~mm}$ ) (Paxinos and Watson, 2014). The cannulae were anchored to the skull with 3 or 4 stainless-steel screws and dental cement. A stainless-steel stylet blocker was inserted into each cannula to keep it patent and to prevent infection. The rats were allowed to recover for at least 1 week after stereotaxic surgery. Catheters were flushed daily with $0.2 \mathrm{ml}$ solution of enrofloxacin $(4 \mathrm{mg} / \mathrm{ml})$ mixed in a heparinized saline solution $(50 \mathrm{IU} / \mathrm{ml}$ in $0.9 \%$ sterile saline) for 1 week after surgery to preserve catheter patency and prevent infection. RO5166017 (1.5 or 5 $\mu \mathrm{g} / 0.5 \mu \mathrm{l} / \mathrm{side}$ ) or vehicle was freshly prepared before the experiments. The drugs were infused bilaterally over $1 \mathrm{~min}$ via microinjection needles, which are $1 \mathrm{~mm}$ longer than the cannulae. The injection needles were kept in place for an additional $1 \mathrm{~min}$ to allow for drug diffusion. The cannula placements were confirmed in $30-\mu$ m-thick sections using Nissl staining under light microscopy after all behavioral tests. Seven rats with misplaced cannulae were excluded from the statistical analysis.

Operant chambers and cocaine self-administration. Twelve standard operant chambers (Med Associates) were used for all cocaine selfadministration studies (Thorn et al., 2014; Liu et al., 2016). Chambers 
contained two response levers; responses on the inactive (left) lever were recorded and had no programmed consequence. Stimulus presentations, cocaine infusions, and data recording were controlled by Med-PC IV software (Med Associates, RRID: SCR_012156).

One week after surgery, rats began to selfadminister cocaine $(0.75 \mathrm{mg} / \mathrm{kg} /$ infusion $)$ for 1 session per day, during which responses to the active lever resulted in intravenous infusions of cocaine under a fixed ratio (FR) schedule of reinforcement followed by a $30 \mathrm{~s}$ time-out period. The response requirement was gradually increased from FR 1 to FR 5 over a period of $5 \mathrm{~d}$ and then maintained for $7 \mathrm{~d}$ under FR 5. Infusions were accompanied by a $5 \mathrm{~s}$ illumination of the stimulus light above the active lever (right) and the house light was extinguished for the duration of the time-out period. Sessions were terminated after either a $2 \mathrm{~h}$ duration or 40 infusions had been earned, whichever occurred first. Following cocaine self-administration sessions, rats were then given 6 daily extinction sessions, during which lever presses had no consequence (no drug or cues). Cue-induced reinstatement was tested $24 \mathrm{~h}$ after the last day of extinction session, during which active lever presses resulted in the presentation of light cues in the same manner as during selfadministration sessions with no drug delivery. Rats were then counterbalanced for drug-induced reinstatement. In the experiment that included three RO5166017 doses, rats were reassigned during the druginduced reinstatement test to ensure that no rats received the same dose of RO5166017 in both tests. Rats were given a $2 \mathrm{~h}$ re-extinction session for $1 \mathrm{~d}$ after the cue-induced reinstatement test, during which lever presses had no programmed consequence (no drug or cues). Drug (10 $\mathrm{mg} / \mathrm{kg}$ cocaine, i.p.)-induced reinstatement was tested $24 \mathrm{~h}$ after reextinction, during which lever presses had no programmed consequence (no drug or cues). RO5166017 or vehicle was microinjected into specific brain regions immediately before cue- and drug-induced reinstatement.

Food reinforcement. Food reinforcement test was conducted according to our previous studies (An et al., 2012; Wang et al., 2016). Experiments were conducted in commercially available chambers located within sound-attenuating, ventilated enclosures (Coulbourn Instruments). Chambers contained two response levers; responses on the inactive (right) lever were recorded and had no programmed consequence. Data were collected using Graphic State 3.03 software and an interface (Coulbourn Instruments). Four groups of rats were trained to press a lever for food under a multiple-cycle procedure. Each cycle began with a $10 \mathrm{~min}$ pretreatment period, during which the chamber was dark and responses had no programmed consequence, followed by a $5 \mathrm{~min}$ response period, during which a light above the active (left) lever was illuminated and rats could receive a maximum of 5 food pellets $(45 \mathrm{mg}$ dustless precision pellets; Bio-Serv) by responding on the active lever. Initially, a single response produced a food pellet; as performance improved, the response requirement was progressively increased across days to a final FR of 5 . The light was terminated after delivery of 5 food pellets or after $5 \mathrm{~min}$ had elapsed, whichever occurred first. Daily sessions consisted of 5 cycles, and rats had to satisfy the following criteria for five consecutive sessions before stereotaxic surgery: the daily response rate, averaged across all 6 cycles within a session, did not vary by more than $\pm 20 \%$ of the average daily response rate of the previous 5 training sessions; and the average response rate among the 5 cycles of a daily session did not vary by more than $\pm 20 \%$. The four groups of rats then received stereotaxic surgery. After recovery from the stereotaxic surgery, rats were retrained to satisfy the criteria before tests. All rats received two tests. Before the first cycle of the first and second tests, rats received a single microinjection of vehicle and RO5166017, respectively. At least two consecutive training sessions that satisfied the test criteria were interspersed between the two tests. The response rates during tests were presented as responses per second.

Locomotor activity test. Locomotor activity was recorded by an infrared motion-sensor system (AccuScan Instruments) fitted outside plastic cages $(40 \times 40 \times 30 \mathrm{~cm})$ (Thorn et al., 2014). The plastic cages contained a thin layer of corn cob bedding and were cleaned between each test session. The fusion activity-monitoring system software monitors infrared beam breaks at a frequency of $0.01 \mathrm{~s}$. The interruption of any beam not interrupted during the previous sample was interpreted as an activity score. The Versa Max animal activity monitoring software monitors the distance the rats traveled in $30 \mathrm{~min}$. The locomotor activity of the rats was measured $24 \mathrm{~h}$ after the drug-induced reinstatement test. RO5166017 or vehicle was microinjected into specific brain regions immediately before the test session started.

Data analysis. All results were presented as mean \pm SEM. qPCR results were analyzed by one-way ANOVA. Self-administration and extinction data and food response rate data were analyzed by two-way repeatedmeasures ANOVA followed by Bonferroni's post hoc test. Cue- and druginduced reinstatement and re-extinction data were analyzed separately for total (nonreinforced) active and inactive lever pressing (one-way ANOVA followed by Bonferroni's post hoc test for the VTA experiment and Student's $t$ test for other brain areas experiments) to compare differences among groups treated with RO5166017 and vehicle. $p<0.05$ was considered statistically significant.

\section{Results}

\section{TAAR1 mRNA is expressed throughout the mesocorticolimbic system}

To examine the TAAR 1 expression in the dopaminergic system, we first detected the TAAR1 mRNA expression in the VTA, the $\mathrm{SN}$, the core and shell of NAc, the PrL and IL of mPFC, and the BLA and CeA of amygdala. Consistent with previous studies (Grandy, 2007), we found that TAAR1 mRNA was expressed in all of these brain areas in rats. To compare the difference of TAAR1 expression levels in these brain regions, we normalized all of the brain regions to the $\mathrm{SN}$, where the expression of TAAR1 was approximately medium among these brain regions. One-way ANOVA was conducted to compare the differential expression of TAAR1 mRNA in these brain regions, indicating a significant effect $\left(F_{(7,24)}=8.28, p<0.0001\right.$; Fig. 1$)$. Highest expression of TAAR1 mRNA was found in the NAc core and shell, and lowest expression was found in the PrL and IL of the mPFC.

\section{Cocaine self-administration training and extinction}

We then tested the effects of microinjection of RO5166017, a selective full agonist of TAAR1, on the reinstatement of cocaine-seeking behavior (Fig. 2a). Rats demonstrated reliable cocaine selfadministration in all experiments. Rats that self-administered cocaine received more infusions (mean \pm SEM: cocaine, $25.26 \pm 0.43$ infusions vs saline, $1.20 \pm 0.20$ infusions; $p<0.05$ ) and higher active lever pressing (mean \pm SEM: cocaine, $137.99 \pm 3.42$ presses vs saline, $7.40 \pm 1.29$ presses; $p<0.05$; Fig. $2 b$ ) compared with saline 

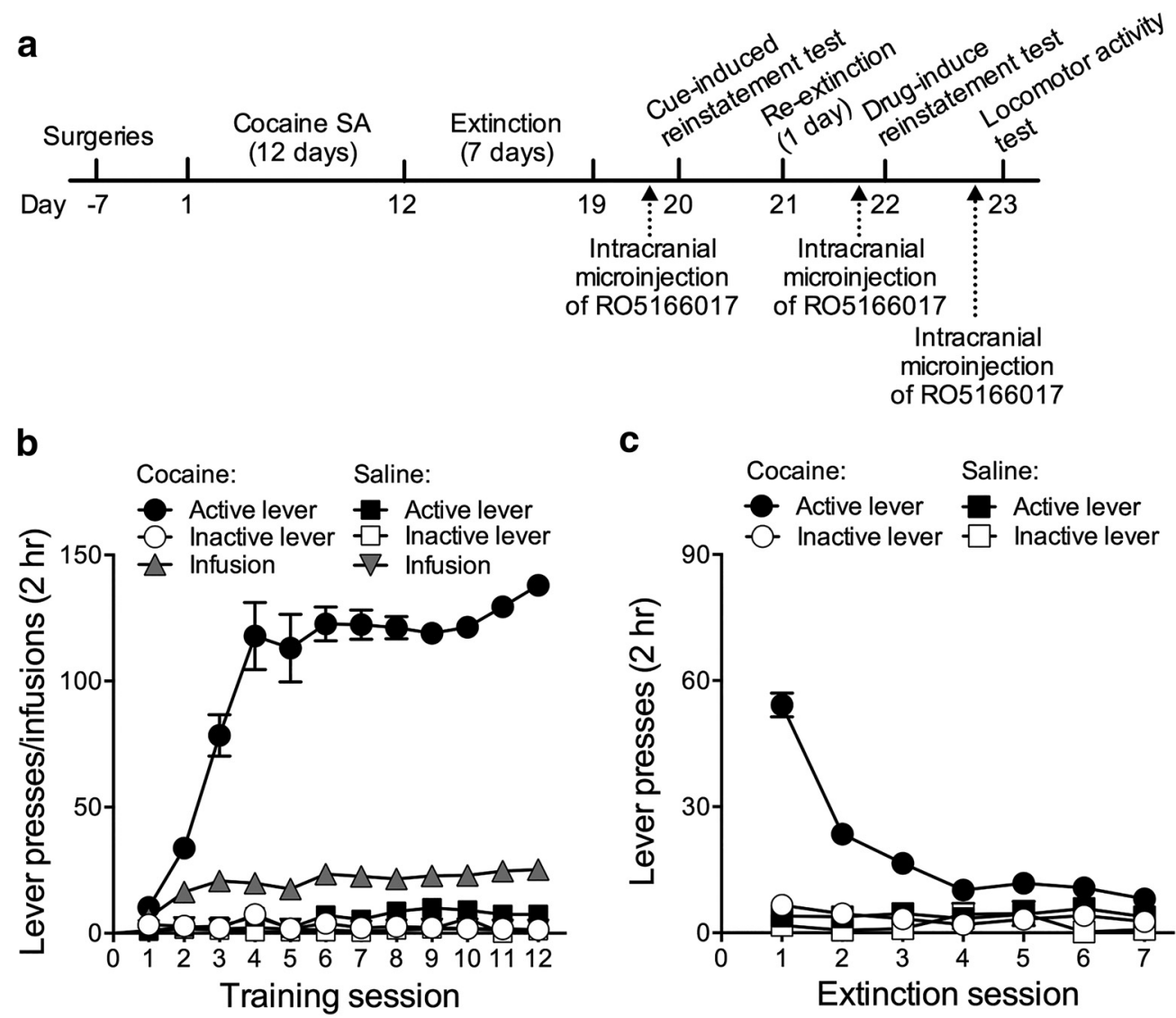

Figure 2. Experimental timeline and cocaine self-administration training and extinction of drug-reinforced responding. $\boldsymbol{a}$, Experimental timeline. $\boldsymbol{b}$, Cocaine self-administration data during training: number of infusions and active and inactive lever presses over the $12 \mathrm{~d}$ of $2 \mathrm{~h}$ daily sessions. $c$, Extinction data: number of nonreinforced active and inactive lever presses over the $7 \mathrm{~d}$ of $2 \mathrm{~h}$ daily extinction sessions. Data are mean \pm SEM. Cocaine, $n=131$; saline, $n=5$.

control rats on the last day of self-administration. Active lever pressing decreased with repeated extinction sessions ( $p<0.05$; Fig. $2 c)$.

\section{Microinjection of RO5166017 into the VTA, but not the SN, prevented both cue- and drug-induced reinstatement of cocaine-seeking behavior}

The brain dopaminergic system is mainly derived from the VTA and the $\mathrm{SN}$, the origins of the mesocorticolimbic and the nigrostriatal dopaminergic systems, respectively. A previous study demonstrated that the TAAR1 full agonist RO5166017 suppressed the activity of DA neurons in the VTA in vitro (Revel et al., 2011). Thus, we first tested the effect of microinjection of RO5166017 into the VTA on the reinstatement of cocaineseeking behavior. RO5166017 ( $1.5 \mu \mathrm{g}$ or $5.0 \mu \mathrm{g} / 0.5 \mu \mathrm{l} /$ side $)$ and vehicle were microinjected into the VTA immediately before the cue- and drug-induced reinstatement tests. One-way ANOVA was conducted to analyze the active lever pressing during cueinduced reinstatement test, which showed a significant difference $\left(F_{(3,20)}=6.94 ; p<0.01\right)$. Post hoc test showed that cocaineassociated cues significantly reinstated responses to the active lever that was associated with cocaine infusion during self-administration sessions (saline-vehicle vs cocaine-vehicle, $t_{(9)}=3.89$, $p<0.001$ ). RO5166017 at a dose of $5.0 \mu \mathrm{g}$, but not $1.5 \mu \mathrm{g}$, per side significantly decreased cue-induced reinstatement (cocainevehicle vs cocaine-5.0 $\mu \mathrm{g}$ RO5166017, $t_{(11)}=4.00, p<0.001$; Fig. $3 a)$. Rats were then re-extinguished $1 \mathrm{~d}$ after the cue-induced reinstatement test. No difference was found during re-extinction (one-way ANOVA, $F_{(3,20)}=0.76, p>0.05$; Fig. $\left.3 b\right)$. Cocaine $(10$ $\mathrm{mg} / \mathrm{kg}$, i.p.)-induced reinstatement of cocaine-seeking was tested $1 \mathrm{~d}$ later. Microinjection of RO5166017 at a dose of $5.0 \mu \mathrm{g}$ per side into the VTA significantly reduced drug-induced reinstatement (one-way ANOVA, $F_{(3,20)}=12.05, p<0.0001$; cocaine-vehicle vs cocaine-5 $\mu \mathrm{g}$ RO5166017, $t_{(11)}=4.10, p<0.05$; Fig. $3 c$ ). No difference was found in inactive lever pressing among all groups during cue- and drug-induced reinstatement tests and reextinction (all $p>0.05$ ). Furthermore, microinjection of RO5166017 into the VTA did not affect the total distance traveled in the locomotor activity test in the same rats (mean \pm SEM: saline-vehicle, $3388 \pm 872.2 \mathrm{~cm}$; cocaine-vehicle, $3142 \pm 509.44$ $\mathrm{cm}$; cocaine- $1.5 \mu \mathrm{g}$ RO5166017, $3144.29 \pm 581.85 \mathrm{~cm}$; cocaine$5.0 \mu \mathrm{g}$ RO5166017, $3274.14 \pm 942.57 \mathrm{~cm}$; all $p>0.05)$. Because the dose of RO5166017 (5.0 $\mu$ g per side) was enough to activate TAAR1 in the VTA and alter the behavior, and because the expression of TAAR1 mRNA in the VTA was relatively high among the tested brain regions, we used this dose of RO5166017 in the following experiments.

We then tested the effect of RO5166017 microinjection into the $\mathrm{SN}$ on the reinstatement of cocaine-seeking behavior. Microinjection of RO5166017 into the $\mathrm{SN}$ had no effect on active lever pressing in cue-induced reinstatement test $\left(t_{(12)}=0.05, p>0.05\right.$; Fig. $\left.3 e\right)$. In addition, no differences of active lever pressing were found during re-extinction $\left(t_{(12)}=0.0, p>0.05\right.$; Fig. $\left.3 f\right)$ and drug-induced reinstatement test $\left(t_{(12)}=0.38, p>0.05\right.$; Fig. $\left.3 g\right)$. No difference was found in inactive lever pressing during cue- and drug-induced reinstatement tests and re-extinction (all $p>0.05$ ). Microinjection of RO5166017 into the SN did not affect the total distance traveled in 
the locomotion test (mean \pm SEM: vehicle, $3666.00 \pm 495.41 \mathrm{~cm}$ vs RO5166017, $3423 \pm 356.00 \mathrm{~cm} ; p>0.05)$. Together, these results indicated that pharmacological activation of TAAR 1 in the VTA, but not the $\mathrm{SN}$, suppressed cue- and drug-induced reinstatement of cocaine-seeking, suggesting the critical role of TAAR1 in the VTA, but not the $\mathrm{SN}$, dopaminergic neurons in the reinstatement of cocaine-seeking.

Microinjection of RO5166017 into the nucleus accumbens core and shell blocked cue- and drug-induced reinstatement of cocaine-seeking, respectively

Dopaminergic projections originating from the VTA to the nucleus accumbens are the primary component of the mesolimbic dopaminergic pathway. Previous studies suggested that the two subregions of the NAc, core and shell, play different roles in drug addiction (Fuchs et al., 2004; Wang et al., 2010). Inactivation of the NAc core, but not shell, with a combination of the $\mathrm{GABA}_{\mathrm{A}}$ receptor agonist muscimol and the $\mathrm{GABA}_{\mathrm{B}}$ agonist baclofen abolished both cue- and drug-induced reinstatement of cocaineseeking (McFarland and Kalivas, 2001; Fuchs et al., 2004). We then tested the effect of microinjection of RO5166017 into the NAc core or shell on the reinstatement of cocaine-seeking behavior. Microinjection of RO5166017 into the NAc core, but not shell, reduced active lever pressing during cue-induced reinstatement test (core, $t_{(14)}=2.29, p<0.05$; shell, $t_{(15)}=0.46, p>$ 0.05 ; Fig. $4 a, e)$. Rats were re-extinguished before the drug-induced reinstatement test of cocaine-seeking. Active lever pressing of two groups has no difference during reextinction (core, $t_{(14)}=0.76, p>0.05$; shell, $t_{(15)}=1.79, p>0.05$; Fig. $\left.4 b, f\right)$. During drug-induced reinstatement test, the active lever pressing was attenuated by microinjection of RO5166017 into the NAc shell, but not NAc core (core, $t_{(14)}=0.64, p>0.05$; shell, $t_{(15)}=2.42, p<0.05$; Fig. $\left.4 c, g\right)$. No difference was found in inactive lever pressing during cue- and drug-induced reinstatement tests and re-extinction (all $p>0.05$ ). Furthermore, the total distance traveled in the locomotor activity test was not changed by microinjection of RO5166017 into either the NAc core (vehicle, $3747.14 \pm 510.64 \mathrm{~cm}$ vs RO5166017, $3911.56 \pm 660.95 \mathrm{~cm} ; p>$ 0.05 ) or the NAc shell (vehicle, $3254.22 \pm$ $398.754 \mathrm{~cm}$ vs RO5166017, $3486.25 \pm$ $176.37 \mathrm{~cm} ; p>0.05)$. These results indicated that TAAR 1 in the NAc core and shell played critical roles in cue- and drug-in-
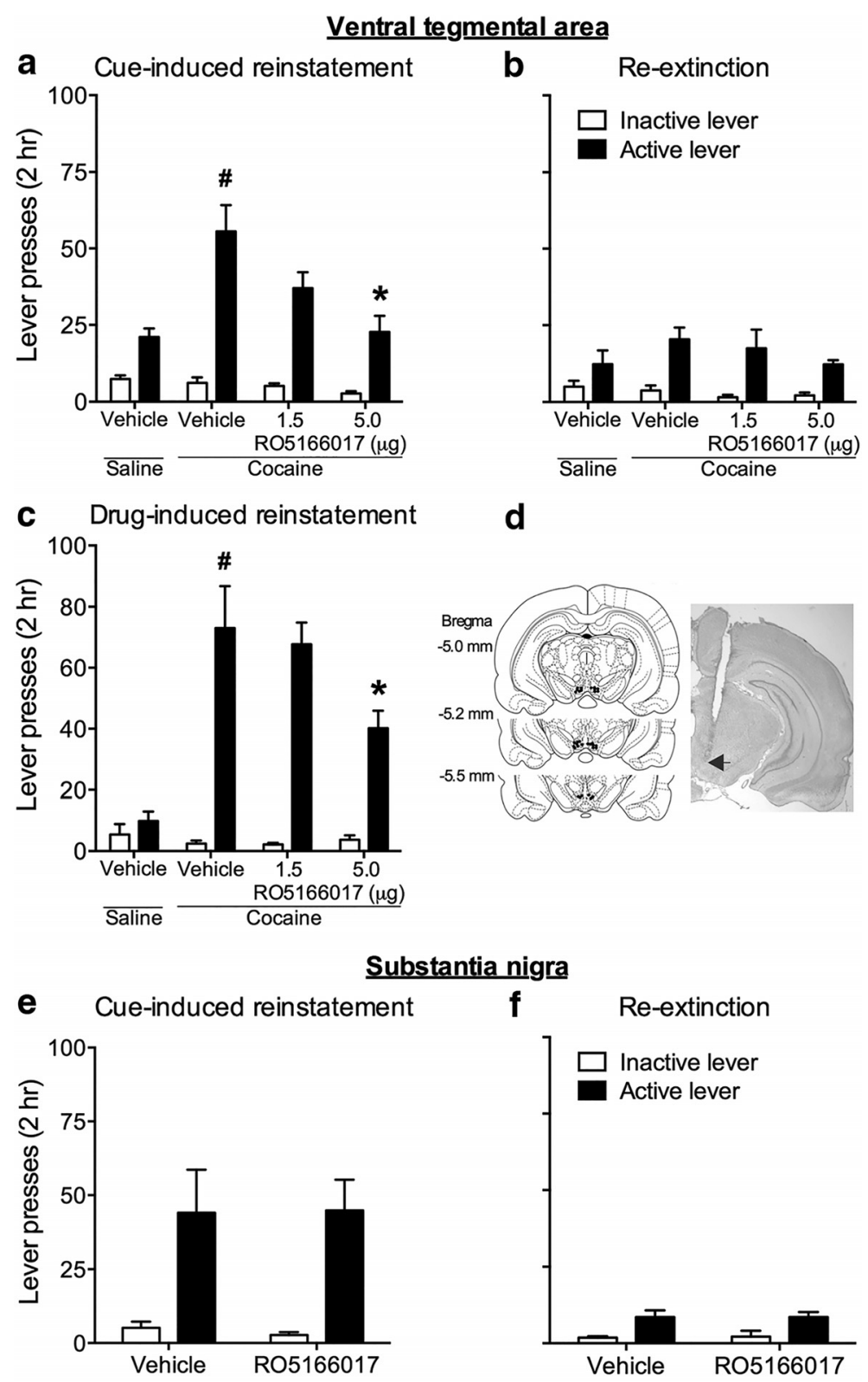

g Drug-induced reinstatement

h
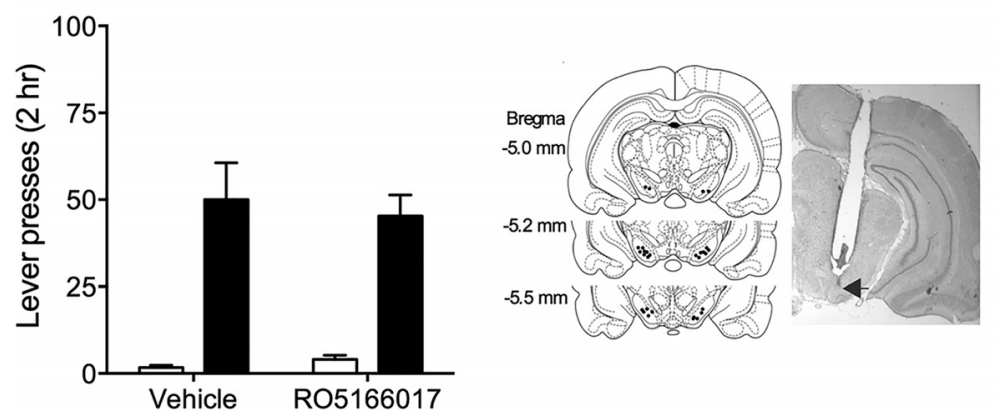

Figure 3. Microinjection of R05166017 into the VTA, but not the SN, prevented both cue- and drug-induced reinstatement of cocaine-seeking behavior. $\boldsymbol{a}, \boldsymbol{e}$, The cocaine-vehicle group of rats that self-administrated cocaine showed higher active lever pressing compared with the saline-vehicle group during cue-induced reinstatement test. Microinjection of R05166017 into the VTA, but not the SN, reduced active lever pressing in the cue-induced reinstatement of cocaine-seeking. $\boldsymbol{b}, \boldsymbol{f}$, No difference was found during re-extinction. $\boldsymbol{c}, \boldsymbol{g}$, Cocaine priming reinstated active lever pressing of the cocaine-vehicle group of rats. Microinjection of R05166017 into the VTA, but not the SN, decreased active lever pressing in the drug-induced reinstatement of cocaineseeking. $\boldsymbol{d}, \boldsymbol{h}$, Microinjection sites for the VTA and the SN. Data are mean \pm SEM. ${ }^{\#} p<0.05$, different from the saline-vehicle group. ${ }^{*} p<0.05$, different from the cocaine-vehicle group. $n=5-7$ per group. 


\section{Nucleus accumbens core}

\section{a Cue-induced reinstatement}

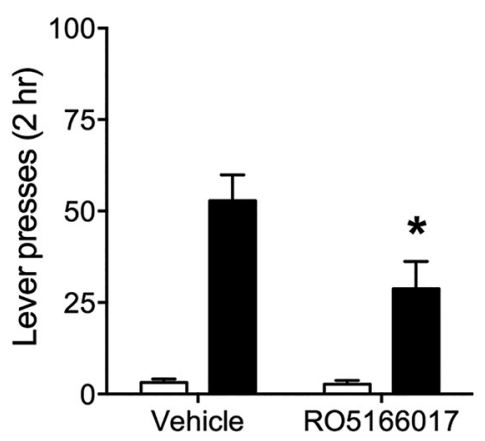

C Drug-induced reinstatement

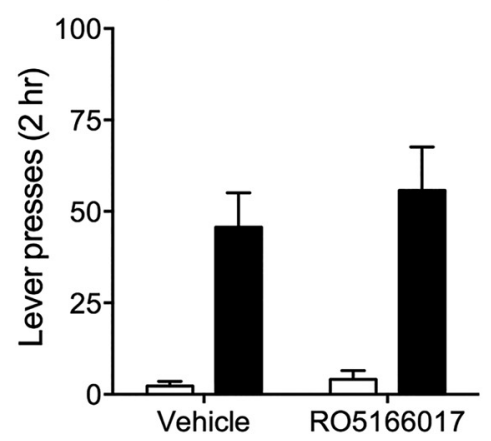

b

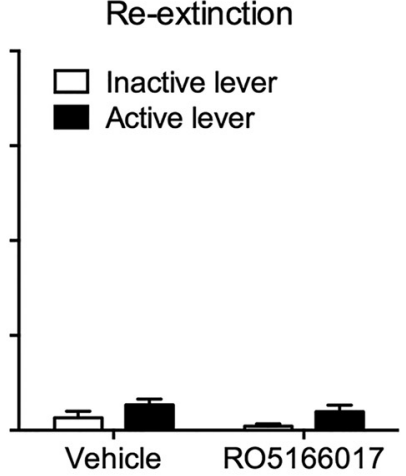

\section{Nucleus accumbens shell}
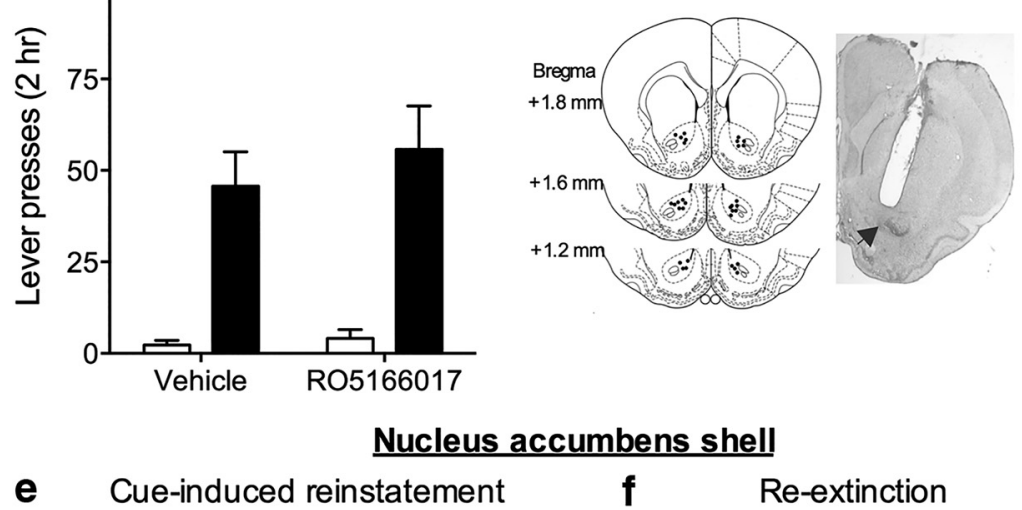

。

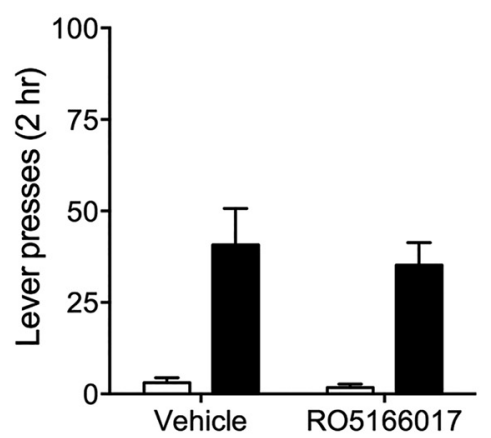

f

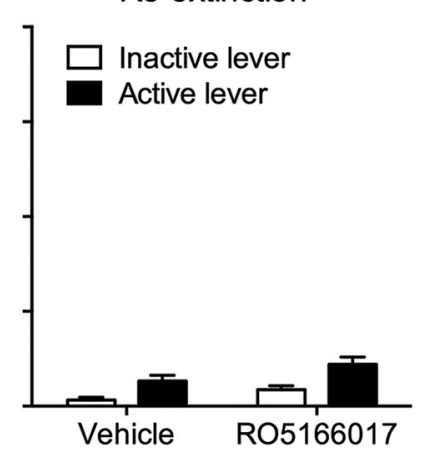

g Drug-induced reinstatement

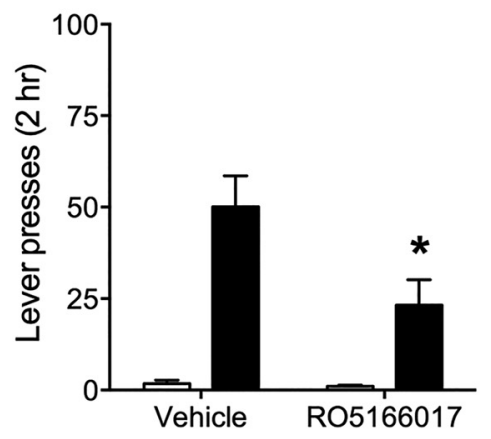

h

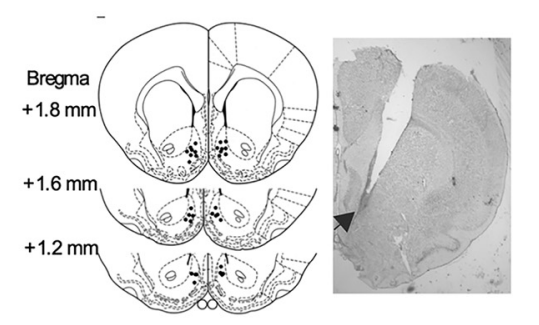

Figure 4. Microinjection of R05166017 into the NAc core and shell reduced cue- and drug-induced reinstatement of cocaineseeking behavior, respectively. $\boldsymbol{a}, \boldsymbol{e}$, Microinjection of R05166017 into the NAc core, but not shell, decreased cue-induced reinstatement of cocaine-seeking. $\boldsymbol{b}, \boldsymbol{f}$, No difference was found during re-extinction. $\boldsymbol{c}, \boldsymbol{g}$, Microinjection of R05166017 into the NAc shell, but not core, decreased drug-induced reinstatement of cocaine-seeking. $\boldsymbol{d}, \boldsymbol{h}$, Microinjection sites for the NAc core and shell. Data are mean \pm SEM. ${ }^{*} p<0.05$, different from the vehicle group. $n=8$ or 9 per group.

duced reinstatement of cocaine-seeking behavior, respectively.

Microinjection of RO5166017 into the PrL, but not IL, blocked cue- and drug-induced reinstatement of cocaine-seeking behavior

We then examined the effect of RO5166017 in the MPFC, one of the major mesocortical projection targets of the VTA, in cocaineseeking behavior. RO5166017 was microinjected into the PrL or the IL subregions of $\mathrm{mPFC}$ before cue- and drug-induced reinstatement of cocaine-seeking. Microinjection of RO5166017 into the PrL, but not IL, blocked cue-induced high responding to active lever (PrL, $t_{(13)}=2.85, p<0.05$; IL, $t_{(16)}=0.42, p>0.05$; Fig. $\left.5 a, e\right)$. Active lever pressing showed no difference during reextinction (PrL, $t_{(13)}=0.13, p>0.05$; IL, $t_{(16)}=0.61, p>0.05$; Fig. 5b,f). Microinjection of RO5166017 into the PrL, but not IL, reduced active lever pressing during druginduced reinstatement test $\left(\mathrm{PrL}, t_{(13)}=\right.$ $2.38, p<0.05$; IL, $t_{(16)}=0.03, p>0.05$; Fig. $5 c, g)$. No difference was found in inactive lever pressing during cue- and drug-induced reinstatement tests and re-extinction (all $p>0.05$ ). The total distance traveled in the locomotor activity test was not changed by microinjection of RO5166017 into the PrL (vehicle, $3861.75 \pm 441.93 \mathrm{~cm}$ vs RO5166017, $3632.44 \pm 440.53 \mathrm{~cm} ; p>$ 0.05 ) or IL (vehicle, $3938.14 \pm 285.27 \mathrm{~cm}$ vs RO5166017, $3517.50 \pm 410.35 \mathrm{~cm} ; p>$ $0.05)$. These results suggested that TAAR1 in the PrL, but not IL, is involved in reinstatement of cocaine-seeking behavior.

Microinjection of RO5166017 into the BLA and CeA had no effect on reinstatement of cocaine-seeking behavior Aside from the NAc and the mPFC, the VTA dopaminergic neurons also project to the amygdala, which also plays an important role in cocaine-related behaviors (See et al., 2003; Fuchs et al., 2005). We then tested the role of TAAR1 in the amygdala in reinstatement of cocaineseeking behavior. RO5166017 was microinjected into the BLA or the CeA, two important subregions of the amygdala in cocaine addiction, before the test of cue- and drug-induced cocaine-seeking behavior. Both cue- and drug-induced high responding to active lever were not affected by microinjection of RO5166017 into the BLA (cue-induced reinstatement, $t_{(14)}=0.78, p>0.05$; re-extinction, $t_{(14)}=$ $0.59, p>0.05$; drug-induced reinstatement, $t_{(14)}=0.05, p>0.05$; Fig. $\left.6 a-c\right)$ or the CeA (cue-induced reinstatement, $t_{(14)}=0.18$, 
$p>0.05$; re-extinction, $t_{(14)}=0.65, p>$ 0.05 ; drug-induced reinstatement, $t_{(14)}=$ $0.54, p>0.05$; Fig. $6 e-g$ ). No difference was found in inactive lever pressing during cueand drug-induced reinstatement tests and re-extinction (all $p>0.05$ ). The total distance traveled in the locomotor activity test was also not changed by the microinjection of RO5166017 into both brain areas (BLA: vehicle, $2319.63 \pm 234.05 \mathrm{~cm}$; RO5166 017, $2300.29 \pm 575.61 \mathrm{~cm}$; CeA: vehicle, $2393.88 \pm 668.08 \mathrm{~cm}$; RO5166017, $2472.88 \pm 353.54 \mathrm{~cm}$; both $p>0.05)$. These results suggested that TAAR 1 in the amygdala is not critical for reinstatement of cocaine-seeking behavior.

To further confirm that the effects of TAAR1 full agonist RO5166017 on cue- and drug-induced reinstatement of cocaineseeking were specific to cocaine reward, we tested the effect of RO5166017 on food reward. Two-way repeated-measures ANOVA showed that the response rate for a food reinforcer was not affected by microinjection of RO5166017 into the VTA $\left(F_{(4,48)}=1.36, p>0.05\right), \operatorname{PrL}\left(F_{(4,56)}=1.64\right.$, $p>0.05)$, NAc core $\left(F_{(4,44)}=1.50, p>\right.$ $0.05)$, or NAc shell $\left(F_{(4,40)}=0.51, p>0.05\right.$; Fig. 7). Together, these results suggested that the role of TAAR1 was specific to cocaine reward but not other natural rewardrelated behavior.

\section{Discussion}

TAAR1 $\mathrm{mRNA}$ expression in the mesocorticolimbic system

TAAR1 mRNA has been found in the limbic system, cortices, and monoaminergic system of the mammalian brain (Borowsky et al., 2001; Bunzow et al., 2001; Miller et al., 2005; Lindemann et al., 2008; Xie et al., 2008; Espinoza et al., 2015a). Consistent with this, using real-time PCR method, the present study also showed that TAAR1 mRNA was expressed in the VTA, SN, mPFC, NAc, and amygdala. In mice, TAAR1 expression is higher in the SN/VTA compared with the PFC and striatum (Di Cara et al., 2011). However, we found that the SN/VTA expressed higher level of TAAR1 mRNA than that in the mPFC in rats. The highest level of TAAR1 mRNA was found in the NAc. These data revealed different patterns of expression of TAAR1 mRNA in mice and rats.

TAAR1 in the VTA regulates cocaine-seeking behaviors

Growing evidence demonstrated that TAAR1 negatively modulates the activities of DA neurons (Lindemann et al., 2008). Application of trace amines, which are endogenous TAAR1 ligands, inhibited the fir-

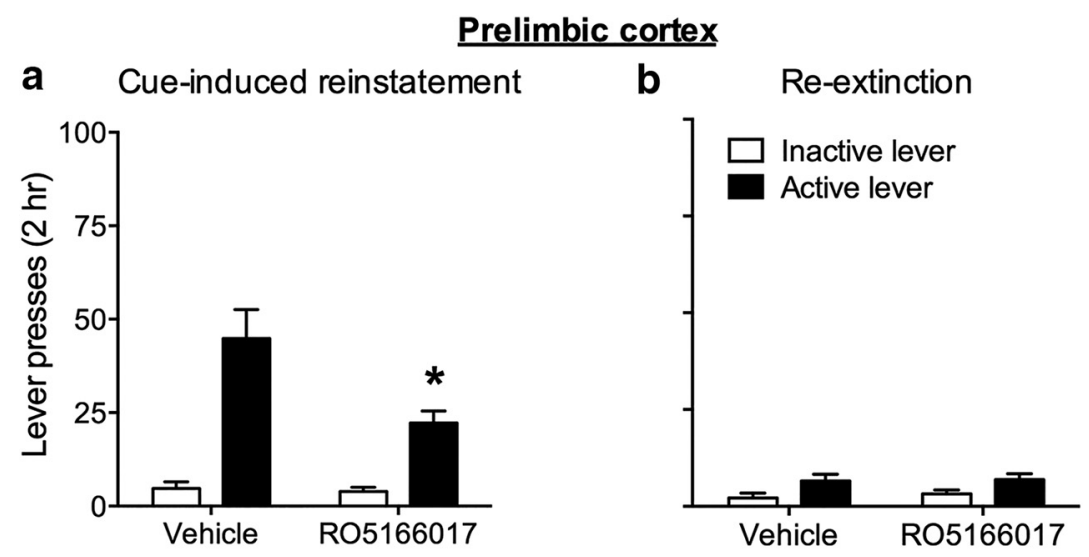

C Drug-induced reinstatement

d

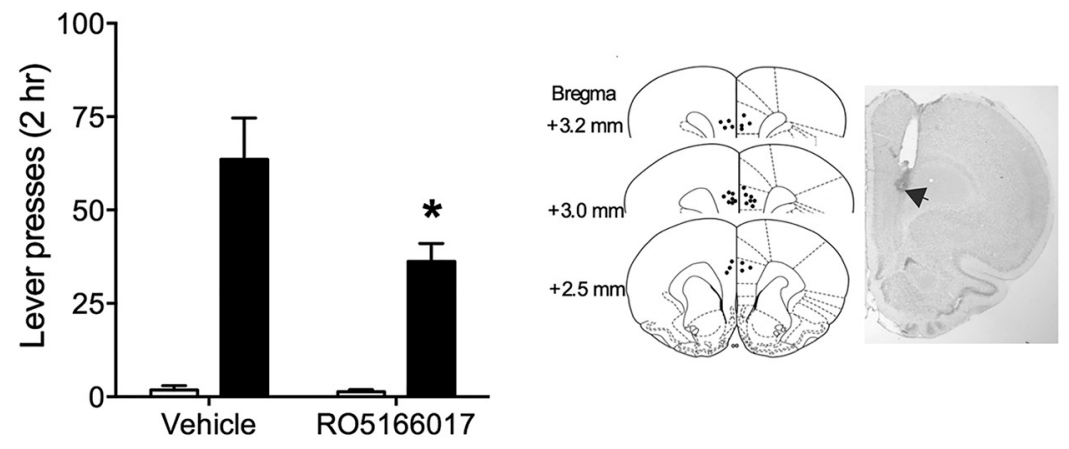

Infralimbic cortex
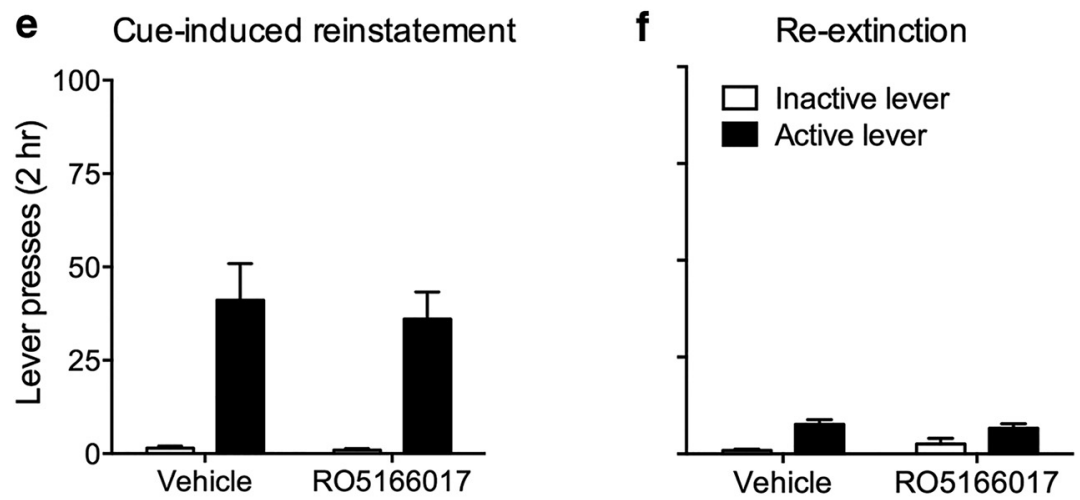

\section{g Drug-induced reinstatement}

h
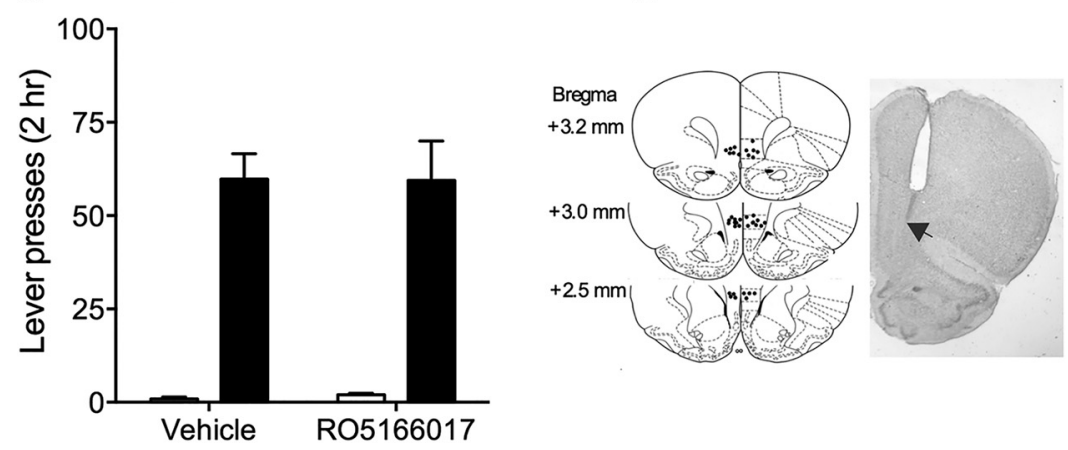

Figure 5. Microinjection of R05166017 into the PrL, but not the IL, of mPFC decreased cue- and drug-induced reinstatement of cocaine-seeking behavior. $\boldsymbol{a}, \boldsymbol{e}$, Microinjection of R05166017 into the PrL, but not IL, decreased cue-induced reinstatement of cocaine-seeking. $\boldsymbol{b}, \boldsymbol{f}$, No difference was found during re-extinction. $\boldsymbol{c}, \boldsymbol{g}$, Microinjection of R05166017 into the PrL, but not IL, decreased drug-induced reinstatement of cocaine-seeking. $\boldsymbol{d}, \boldsymbol{h}$, Microinjection sites for the PrL and the IL. Data are mean \pm SEM. ${ }^{*} p<0.05$, different from the vehicle group. $n=7-9$ per group. 


\section{Basolateral amy.gdala}
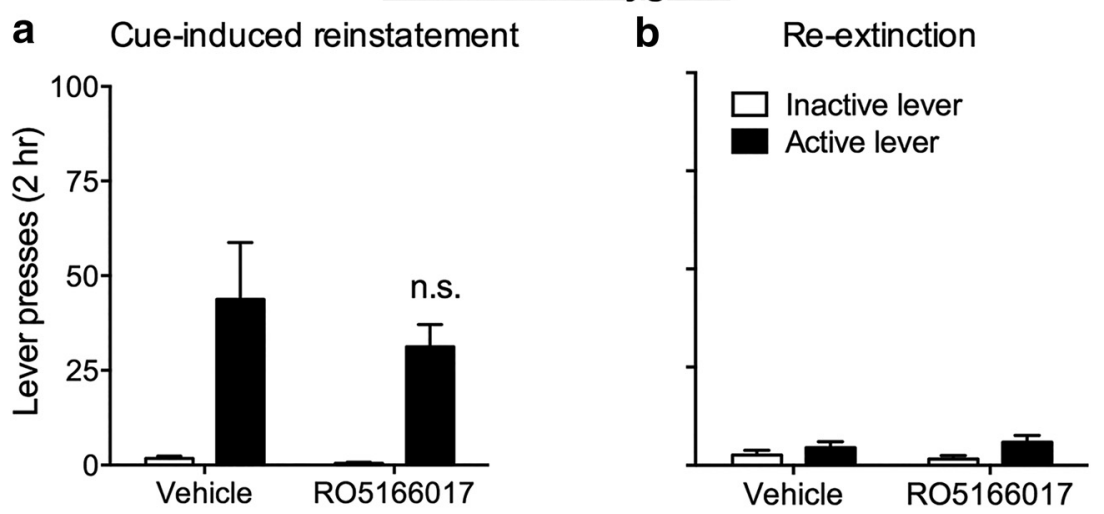

C Drug-induced reinstatement

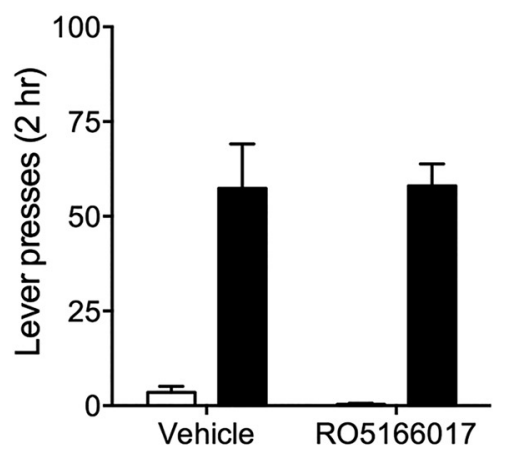

d

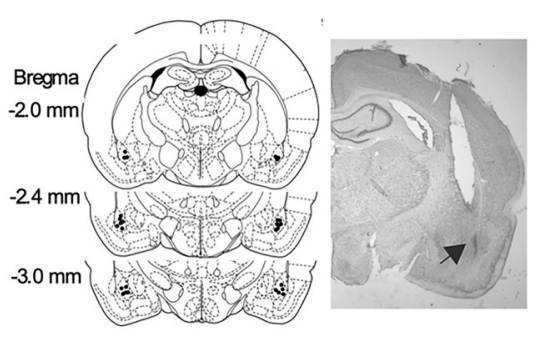

Central amygdala

e
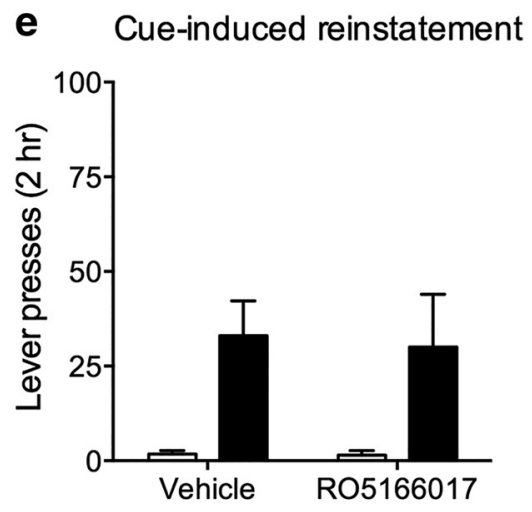

$\mathbf{f}$

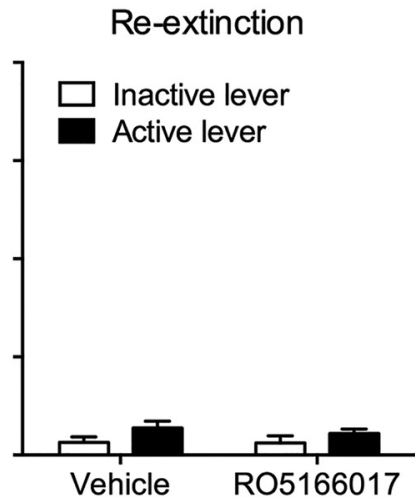

g Drug-induced reinstatement

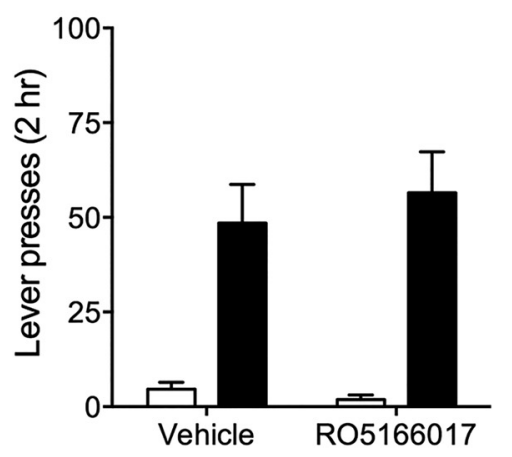

ing activity of dopaminergic neurons of the SN and VTA in vitro (Geracitano et al., 2004). Selective TAAR1 full agonists also inhibited the firing rate of dopaminergic neurons in the VTA (Revel et al., 2011, 2012b, 2013). Furthermore, TAAR1 ${ }^{-I-}$ mice showed an increase in the firing rate of dopaminergic neurons in the VTA (Lindemann et al., 2008). A selective TAAR1 antagonist, EPPTB, increased the firing rate of DA neurons and blocked TAAR1 agonistinduced decrease in the firing frequency of DA neurons of the VTA (Bradaia et al., 2009). Consistent with these results, our present finding showed that microinjection of RO5166017 into the VTA prevented the cue- and drug-induced reinstatement of cocaine-seeking behaviors.

Although TAAR1 regulates the activity of dopaminergic neurons in the $\mathrm{SN}$ in vitro (Geracitano et al., 2004), activation of TAAR1 in the SN did not affect reinstatement of cocaine-seeking behavior. This is consistent with the idea that the VTA/ ventral striatum, but not the SN/dorsal striatum dopaminergic system, plays a key role in mediating the rewarding effects of abused drugs (Kauer and Malenka, 2007). Consistent with this, TAAR1 partial and full agonists dose-dependently attenuated cocaine-induced lowering of intra-VTA selfstimulation thresholds (Pei et al., 2015). A recent study showed that activation of dorsal striatal TAAR1 reduced L-DOPA-induced behavioral response and activity of AMPAR subunit glutamate receptor 1 , suggesting a role of the dorsal striatal TAAR1 in the degeneration of dopaminergic neurons and related behaviors (Alvarsson et al., 2015).

Interestingly, the activated signaling cascades by TAAR1 activation can be blocked by concurrent $\mathrm{D} 2$ activation, suggesting that D2 signaling may compete against TAAR1 signaling (Geracitano et al., 2004; Xie et al., 2007). Knock-out of TAAR1 or pharmacological inhibition of TAAR1 increased the potency of DA at D2 receptors, whereas TAAR1 activation reduced the potency of DA D2 receptor agonists at the DA neurons within the VTA (Wolinsky et al., 2007; Bradaia et al., 2009). Together, these results therefore suggested that TAAR1 might control the activities of DA neurons in the VTA via interacting with $\mathrm{D} 2$ autoreceptors.

TAAR1 in the nucleus accumbens regulates cocaine-seeking behaviors Increased DA release by drugs of abuse in the NAc, one of the main terminals of DA neurons in the VTA, mediates the rewarding effect of addictive drugs and related behaviors (Kauer and Malenka, 2007).
Figure 6. Microinjection of R05166017 into the BLA and the CeA had no effect on cue- and drug-induced reinstatement of cocaine-seeking behavior. $\boldsymbol{a}, \boldsymbol{e}$, Microinjection of R05166017 into the BLA and the CeA had no effect on cue-induced reinstatement of cocaine-seeking. $\boldsymbol{b}, \boldsymbol{f}$, No difference was found during re-extinction. $\boldsymbol{c}, \boldsymbol{g}$, Microinjection of R05166017 into the BLA and the CeA did not affect drug-induced reinstatement of cocaine-seeking. $\boldsymbol{d}, \boldsymbol{h}$, Microinjection sites for the BLA and the CeA. Data are mean \pm SEM. ${ }^{*} p<0.05$, different from the vehicle group. $n=8$ per group. 

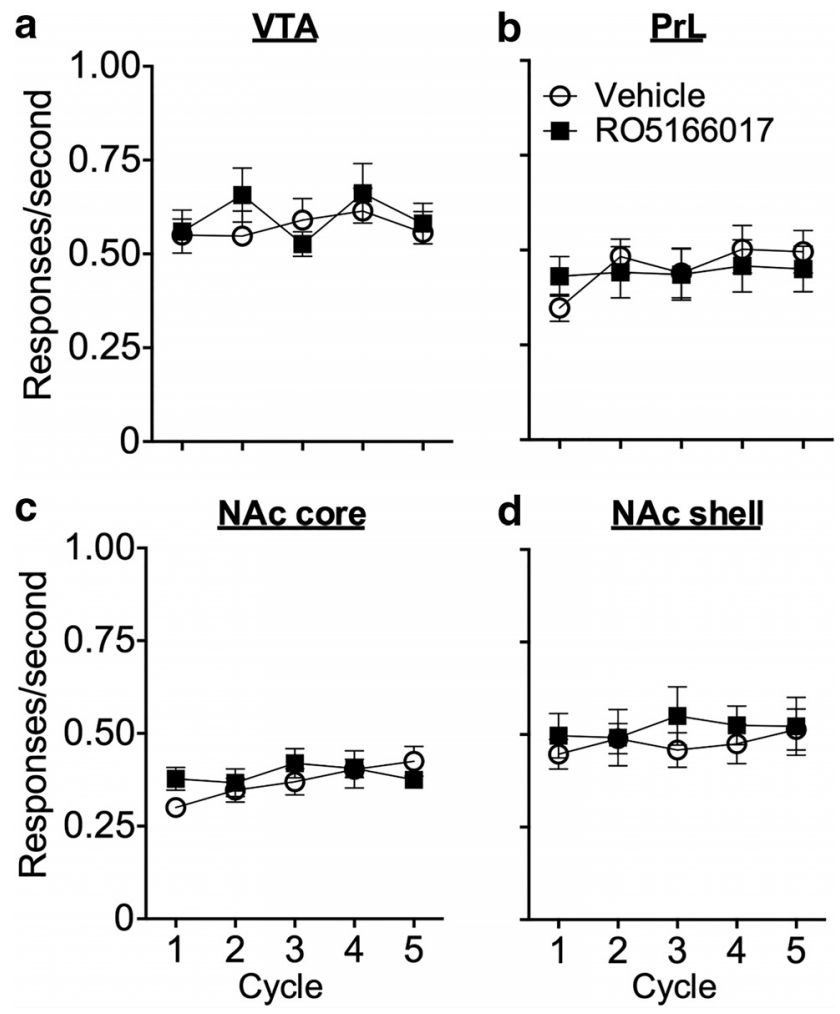

Figure 7. Microinjection of R05166017 into the VTA, PrL, NAc core, or NAc shell had no effect on the response rate for a food reinforcer. $\boldsymbol{a}-\boldsymbol{d}$, After recovery from the stereotaxic surgery, rats were retrained to satisfy the criteria before tests. All rats received two tests. Before the first cycle of the first and second tests, rats received a single microinjection of vehicle and R05166017, respectively. Microinjection of R05166017 into the VTA, the PrL, the NAc core, or the NAc shell did not affect the response rate for a food reward. Data are mean \pm SEM. $n=6-8$ per group.

Although the basal extracellular level of neurotransmitters, including DA in TAAR $1^{-/-}$mice, was not changed, amphetamineinduced DA release in the NAc was augmented (Lindemann et al., 2008). Moreover, the basal extracellular concentrations of DA in the NAc were higher in mice overexpressing TAAR1 (Revel et al., 2012a).

It is proposed that TAAR1 could modulate the local presynaptic DA release and reuptake in the NAc. In cultured cells overexpressing TAAR1 and DAT, TAAR1 can interact with DAT to regulate the reuptake of DA, suggesting that DA release regulated by TAAR1 may interact with presynaptic DAT to regulate the reuptake of DA (Xie and Miller, 2007, 2009b). However, a TAAR1 full agonist blocked cocaine-induced hyperactivity in $\mathrm{DAT}^{-/-}$mice, which indicated that TAAR1 could regulate cocaine-related behaviors through DAT-independent mechanisms. A recent study showed that the postsynaptic D2 receptor might also be involved in the function of TAAR1. TAAR1 ${ }^{-1-}$ mice showed hypersensitivity of postsynaptic D2 receptors in the striatum (Espinoza et al., 2015a). Together, TAAR1 in the NAc could regulate cocaine-related behavior by modulating D2 receptor signaling.

The NAc core and shell are neuroanatomically dissociable heterogeneous structures with distinct afferent and efferent connections (Zahm and Brog, 1992). Previous results indicated that the NAc core and shell are differentially involved in cue- and drug-induced reinstatement of cocaine-seeking. Inactivation of the NAc core by the mixture of muscimol and baclofen attenuated, whereas inactivation of the NAc shell increased or did not affect, cue-induced reinstatement of cocaine-seeking (Fuchs et al., 2004; Di Ciano et al., 2008). The mammalian target of rapamycin signaling pathway in the NAc core, but not shell, is critical for cue-induced reinstatement of cocaine-seeking (Wang et al., 2010). In contrast, the activity of $\mathrm{Ca}^{2+} /$ calmodulin-dependent protein kinase II in the NAc shell, but not core, is involved in drug-induced reinstatement of cocaine-seeking (Anderson et al., 2008). Accordingly, the present finding showed that activation of TAAR1 in the NAc core and shell differentially regulates cue- and drug-induced reinstatement of cocaine-seeking behavior.

\section{TAAR1 in the prefrontal cortex regulates} cocaine-seeking behaviors

The present study also found that TAAR1 activation in the PrL subregion of $\mathrm{MPFC}$ inhibited both cue- and drug-induced reinstatement of cocaine-seeking. However, TAAR1 activation in the IL, the ventral portion of mPFC, had no effect on reinstatement of cocaine-seeking. This result is in agreement with a large body of evidence that supports the dissociated roles of PrL and IL of mPFC in cocaine-seeking (Peters et al., 2009; Moorman et al., 2015). It is proposed that the PrL and IL exert opposing effects on several behaviors, including drug addiction (Gourley and Taylor, 2016). The PrL positively controls the conditioned response, and inactivation of the PrL could reduce both cue- and drug-induced cocaine-seeking (Miller and Marshall, 2004; Di Pietro et al., 2006). Instead, IL has proven to play an essential role in the extinction of conditioned response, and inactivation of IL following extinction could augment the reinstatement of cocaineseeking (Peters et al., 2008a, b, 2009).

Consistent with this, a recent study also showed that TAAR1 plays a role in PFC-related processes and functions. Compared with WT, TAAR $1^{-1-}$ mice showed NMDA receptor-dependent synaptic deficits in mPFC. Furthermore, RO5166017 could mildly increase the GluN1 expression and a significant increase in the phosphorylation of GluN1 in cultured cortical neurons. Although systemic administration of TAAR1 full agonists might reduce the activity of $\mathrm{MPFC}$ via decreasing dopaminergic neurons of the VTA projecting to the mPFC, TAAR1 full agonists could also enhance the MPFC function by augmenting local glutamatergic activity (Revel et al., 2011; Espinoza et al., 2015b).

\section{TAAR1 in the amygdala is not involved in} cocaine-seeking behaviors

Although the amygdala plays a crucial role in the reinstatement of cocaine-seeking (Luo et al., 2013), we did not observe any difference in the reinstatement of cocaine-seeking behavior when the TAAR1 full agonist was microinjected into the BLA or CeA subregions of the amygdala. This was not because the agonist dose used is too low to activate the TAAR1 in the amygdala. The level of TAAR 1 mRNA in the amygdala is less than that in the NAc, and the same dose of RO5166017 in the NAc significantly reduced the reinstatement of cocaine-seeking. However, TAAR1 in the amygdala could be involved in other emotion-related behaviors (e.g., stress-induced reinstatement of cocaine-seeking) (Revel et al., 2013; Wenzel et al., 2014; Mantsch et al., 2016), which requires further investigation.

Systemic administration of TAAR1 agonists would affect the reinstatement of cocaine-seeking by modulating several neural circuitries in a synergic manner. Although the effects of TAAR1 full agonists and TAAR1 partial agonists on cocaine-related behaviors are similar, TAAR1 full agonist decreased, but TAAR1 partial agonists increased the firing rate of DA neurons in the VTA in vitro (Revel et al., 2011; Leo et al., 2014; Pei et al., 2014; Thorn et al., 2014; Liu et al., 2016). TAAR1 full agonist 
RO5166017 reduced electrically evoked DA release in the NAc and TAAR1 partial agonist RO5203648 prevented cocaineinduced DA overflow (Leo et al., 2014; Pei et al., 2014), suggesting that TAAR1 in the NAc could be the most important target that plays a critical role in cocaine-related behavior.

In conclusion, TAAR1 in several brain regions of mesocorticolimbic DA system differentially participates in the reinstatement of cocaine-seeking. These results suggest that, although the precise cellular mechanisms of TAAR1 function in specific brain regions may be distinct, which might in turn depend on the neural microcircuitry in the local regions, TAAR1 in different brain regions of mesocorticolimbic system may function together to reduce cocaine-related behaviors.

\section{References}

Alvarsson A, Zhang X, Stan TL, Schintu N, Kadkhodaei B, Millan MJ, Perlmann T, Svenningsson P (2015) Modulation by trace amine-associated receptor 1 of experimental parkinsonism, L-DOPA responsivity, and glutamatergic neurotransmission. J Neurosci 35:14057-14069. CrossRef Medline

An XF, Zhang Y, Winter JC, Li JX (2012) Effects of imidazoline I(2) receptor agonists and morphine on schedule-controlled responding in rats. Pharmacol Biochem Behav 101:354-359. CrossRef Medline

Anderson SM, Famous KR, Sadri-Vakili G, Kumaresan V, Schmidt HD, Bass CE, Terwilliger EF, Cha JH, Pierce RC (2008) CaMKII: a biochemical bridge linking accumbens dopamine and glutamate systems in cocaine seeking. Nat Neurosci 11:344-353. CrossRef Medline

Borowsky B, Adham N, Jones KA, Raddatz R, Artymyshyn R, Ogozalek KL, Durkin MM, Lakhlani PP, Bonini JA, Pathirana S, Boyle N, Pu X, Kouranova E, Lichtblau H, Ochoa FY, Branchek TA, Gerald C (2001) Trace amines: identification of a family of mammalian G-protein-coupled receptors. Proc Natl Acad Sci U S A 98:8966-8971. CrossRef Medline

Bossert JM, Marchant NJ, Calu DJ, Shaham Y (2013) The reinstatement model of drug relapse: recent neurobiological findings, emerging research topics, and translational research. Psychopharmacology (Berl) 229:453476. CrossRef Medline

Bradaia A, Trube G, Stalder H, Norcross RD, Ozmen L, Wettstein JG, Pinard A, Buchy D, Gassmann M, Hoener MC, Bettler B (2009) The selective antagonist EPPTB reveals TAAR1-mediated regulatory mechanisms in dopaminergic neurons of the mesolimbic system. Proc Natl Acad Sci U S A 106:20081-20086. CrossRef Medline

Bunzow JR, Sonders MS, Arttamangkul S, Harrison LM, Zhang G, Quigley DI, Darland T, Suchland KL, Pasumamula S, Kennedy JL, Olson SB, Magenis RE, Amara SG, Grandy DK (2001) Amphetamine, 3,4-methylenedioxymethamphetamine, lysergic acid diethylamide, and metabolites of the catecholamine neurotransmitters are agonists of a rat trace amine receptor. Mol Pharmacol 60:1181-1188. CrossRef Medline

Burchett SA, Hicks TP (2006) The mysterious trace amines: protean neuromodulators of synaptic transmission in mammalian brain. Prog Neurobiol 79:223-246. CrossRef Medline

Carpenter MB, Peter P (1972) Nigrostriatal and nigrothalamic fibers in the rhesus monkey. J Comp Neurol 144:93-115. CrossRef Medline

Chai N, Liu JF, Xue YX, Yang C, Yan W, Wang HM, Luo YX, Shi HS, Wang JS, Bao YP, Meng SQ, Ding ZB, Wang XY, Lu L (2014) Delayed noradrenergic activation in the dorsal hippocampus promotes the long-term persistence of extinguished fear. Neuropsychopharmacology 39:1933-1945. CrossRef Medline

Chronister RB, Sikes RW, Wood J, DeFrance JF (1980) The pattern of termination of ventral tegmental afferents into nucleus accumbens: an anterograde HRP analysis. Neurosci Lett 17:231-235. CrossRef Medline

de Wit H, Stewart J (1981) Reinstatement of cocaine-reinforced responding in the rat. Psychopharmacology (Berl) 75:134-143. CrossRef Medline

Di Cara B, Maggio R, Aloisi G, Rivet JM, Lundius EG, Yoshitake T, Svenningsson P, Brocco M, Gobert A, De Groote L, Cistarelli L, Veiga S, De Montrion C, Rodriguez M, Galizzi JP, Lockhart BP, Cogé F, Boutin JA, Vayer P, Verdouw PM, et al. (2011) Genetic deletion of trace amine 1 receptors reveals their role in auto-inhibiting the actions of ecstasy (MDMA). J Neurosci 31:16928-16940. CrossRef Medline

Di Ciano P, Robbins TW, Everitt BJ (2008) Differential effects of nucleus accumbens core, shell, or dorsal striatal inactivations on the persistence, reacquisition, or reinstatement of responding for a drug-paired conditioned reinforcer. Neuropsychopharmacology 33:1413-1425. CrossRef Medline

Di Pietro NC, Black YD, Kantak KM (2006) Context-dependent prefrontal cortex regulation of cocaine self-administration and reinstatement behaviors in rats. Eur J Neurosci 24:3285-3298. CrossRef Medline

Espinoza S, Ghisi V, Emanuele M, Leo D, Sukhanov I, Sotnikova TD, Chieregatti E, Gainetdinov RR (2015a) Postsynaptic D2 dopamine receptor supersensitivity in the striatum of mice lacking TAAR1. Neuropharmacology 93:308-313. CrossRef Medline

Espinoza S, Lignani G, Caffino L, Maggi S, Sukhanov I, Leo D, Mus L, Emanuele M, Ronzitti G, Harmeier A, Medrihan L, Sotnikova TD, Chieregatti E, Hoener MC, Benfenati F, Tucci V, Fumagalli F, Gainetdinov RR (2015b) TAAR1 modulates cortical glutamate NMDA receptor function. Neuropsychopharmacology 40:2217-2227. CrossRef Medline

Fuchs RA, Evans KA, Parker MC, See RE (2004) Differential involvement of the core and shell subregions of the nucleus accumbens in conditioned cue-induced reinstatement of cocaine seeking in rats. Psychopharmacology (Berl) 176:459-465. CrossRef Medline

Fuchs RA, Evans KA, Ledford CC, Parker MP, Case JM, Mehta RH, See RE (2005) The role of the dorsomedial prefrontal cortex, basolateral amygdala, and dorsal hippocampus in contextual reinstatement of cocaine seeking in rats. Neuropsychopharmacology 30:296-309. CrossRef Medline

Gancarz AM, Wang ZJ, Schroeder GL, Damez-Werno D, Braunscheidel KM, Mueller LE, Humby MS, Caccamise A, Martin JA, Dietz KC, Neve RL, Dietz DM (2015) Activin receptor signaling regulates cocaine-primed behavioral and morphological plasticity. Nat Neurosci 18:959-961. CrossRef Medline

Geracitano R, Federici M, Prisco S, Bernardi G, Mercuri NB (2004) Inhibitory effects of trace amines on rat midbrain dopaminergic neurons. Neuropharmacology 46:807-814. CrossRef Medline

Gourley SL, Taylor JR (2016) Going and stopping: dichotomies in behavioral control by the prefrontal cortex. Nat Neurosci 19:656-664. CrossRef Medline

Grandy DK (2007) Trace amine-associated receptor 1-Family archetype or iconoclast? Pharmacol Ther 116:355-390. CrossRef Medline

Hattori T, Fibiger HC, McGeer PL, Maler L (1973) Analysis of the fine structure of the dopaminergic nigrostriatal projection by electron microscopic autoradiography. Exp Neurol 41:599-611. CrossRef Medline

Jing L, Li JX (2015) Trace amine-associated receptor 1: a promising target for the treatment of psychostimulant addiction. Eur J Pharmacol 761: 345-352. CrossRef Medline

Kalivas PW, McFarland K (2003) Brain circuitry and the reinstatement of cocaineseeking behavior. Psychopharmacology (Berl) 168:44-56. CrossRef Medline

Kauer JA, Malenka RC (2007) Synaptic plasticity and addiction. Nat Rev Neurosci 8:844-858. CrossRef Medline

Leo D, Mus L, Espinoza S, Hoener MC, Sotnikova TD, Gainetdinov RR (2014) Taar1-mediated modulation of presynaptic dopaminergic neurotransmission: role of D2 dopamine autoreceptors. Neuropharmacology 81:283-291. CrossRef Medline

Lindemann L, Meyer CA, Jeanneau K, Bradaia A, Ozmen L, Bluethmann H, Bettler B, Wettstein JG, Borroni E, Moreau JL, Hoener MC (2008) Trace amine-associated receptor 1 modulates dopaminergic activity. J Pharmacol Exp Ther 324:948-956. CrossRef Medline

Liu JF, Yang C, Deng JH, Yan W, Wang HM, Luo YX, Shi HS, Meng SQ, Chai BS, Fang Q, Chai N, Xue YX, Sun J, Chen C, Wang XY, Wang JS, Lu L (2015) Role of hippocampal beta-adrenergic and glucocorticoid receptors in the novelty-induced enhancement of fear extinction. J Neurosci 35:8308-8321. CrossRef Medline

Liu JF, Thorn DA, Zhang Y, Li JX (2016) Effects of trace amine-associated receptor 1 agonists on the expression, reconsolidation, and extinction of cocaine reward memory. Int J Neuropsychopharmacol 19:piipyw009. CrossRef Medline

Luo YX, Xue YX, Shen HW, Lu L (2013) Role of amygdala in drug memory. Neurobiol Learn Mem 105:159-173. CrossRef Medline

Mantsch JR, Baker DA, Funk D, Lê AD, Shaham Y (2016) Stress-induced reinstatement of drug seeking: 20 years of progress. Neuropsychopharmacology 41:335-356. CrossRef Medline

McFarland K, Kalivas PW (2001) The circuitry mediating cocaine-induced reinstatement of drug-seeking behavior. J Neurosci 21:8655-8663. Medline 
Miller CA, Marshall JF (2004) Altered prelimbic cortex output during cueelicited drug seeking. J Neurosci 24:6889-6897. CrossRef Medline

Miller GM, Verrico CD, Jassen A, Konar M, Yang H, Panas H, Bahn M, Johnson R, Madras BK (2005) Primate trace amine receptor 1 modulation by the dopamine transporter. J Pharmacol Exp Ther 313:983-994. CrossRef Medline

Moorman DE, James MH, McGlinchey EM, Aston-Jones G (2015) Differential roles of medial prefrontal subregions in the regulation of drug seeking. Brain Res 1628:130-146. CrossRef Medline

Oades RD, Halliday GM (1987) Ventral tegmental (A10) system: neurobiology: 1. Anatomy and connectivity. Brain Res 434:117-165. Medline

Paxinos G, Watson C (2014) The rat brain in stereotaxic coordinates, Ed 7. Amsterdam: Elsevier.

Pei Y, Lee J, Leo D, Gainetdinov RR, Hoener MC, Canales JJ (2014) Activation of the trace amine-associated receptor 1 prevents relapse to cocaine seeking. Neuropsychopharmacology 39:2299-2308. CrossRef Medline

Pei Y, Mortas P, Hoener MC, Canales JJ (2015) Selective activation of the trace amine-associated receptor 1 decreases cocaine's reinforcing efficacy and prevents cocaine-induced changes in brain reward thresholds. Prog Neuropsychopharmacol Biol Psychiatry 63:70-75. CrossRef Medline

Pei Y, Asif-Malik A, Canales JJ (2016) Trace amines and the trace amineassociated receptor 1: pharmacology, neurochemistry, and clinical implications. Front Neurosci 10:148. CrossRef Medline

Peters J, LaLumiere RT, Kalivas PW (2008a) Infralimbic prefrontal cortex is responsible for inhibiting cocaine seeking in extinguished rats. J Neurosci 28:6046-6053. CrossRef Medline

Peters J, Vallone J, Laurendi K, Kalivas PW (2008b) Opposing roles for the ventral prefrontal cortex and the basolateral amygdala on the spontaneous recovery of cocaine-seeking in rats. Psychopharmacology (Berl) 197: 319-326. CrossRef Medline

Peters J, Kalivas PW, Quirk GJ (2009) Extinction circuits for fear and addiction overlap in prefrontal cortex. Learn Mem 16:279-288. CrossRef Medline

Revel FG, Moreau JL, Gainetdinov RR, Bradaia A, Sotnikova TD, Mory R, Durkin S, Zbinden KG, Norcross R, Meyer CA, Metzler V, Chaboz S, Ozmen L, Trube G, Pouzet B, Bettler B, Caron MG, Wettstein JG, Hoener MC (2011) TAAR1 activation modulates monoaminergic neurotransmission, preventing hyperdopaminergic and hypoglutamatergic activity. Proc Natl Acad Sci U S A 108:8485-8490. CrossRef Medline

Revel FG, Meyer CA, Bradaia A, Jeanneau K, Calcagno E, André CB, Haenggi M, Miss MT, Galley G, Norcross RD, Invernizzi RW, Wettstein JG, Moreau JL, Hoener MC (2012a) Brain-specific overexpression of trace amine-associated receptor 1 alters monoaminergic neurotransmission and decreases sensitivity to amphetamine. Neuropsychopharmacology 37:2580-2592. CrossRef Medline

Revel FG, Moreau JL, Gainetdinov RR, Ferragud A, Velázquez-Sanchez C, Sotnikova TD, Morairty SR, Harmeier A, Groebke Zbinden K, Norcross RD, Bradaia A, Kilduff TS, Biemans B, Pouzet B, Caron MG, Canales JJ, Wallace TL, Wettstein JG, Hoener MC (2012b) Trace amine-associated receptor 1 partial agonism reveals novel paradigm for neuropsychiatric therapeutics. Biol Psychiatry 72:934-942. CrossRef Medline

Revel FG, Moreau JL, Pouzet B, Mory R, Bradaia A, Buchy D, Metzler V, Chaboz S, Groebke Zbinden K, Galley G, Norcross RD, Tuerck D, Bruns A, Morairty SR, Kilduff TS, Wallace TL, Risterucci C, Wettstein JG, Hoener MC (2013) A new perspective for schizophrenia: TAAR1 agonists reveal antipsychotic- and antidepressant-like activity, improve cognition and control body weight. Mol Psychiatry 18:543-556. CrossRef Medline Schmidt HD, Anderson SM, Famous KR, Kumaresan V, Pierce RC (2005)
Anatomy and pharmacology of cocaine priming-induced reinstatement of drug seeking. Eur J Pharmacol 526:65-76. CrossRef Medline

See RE, McLaughlin J, Fuchs RA (2003) Muscarinic receptor antagonism in the basolateral amygdala blocks acquisition of cocaine-stimulus association in a model of relapse to cocaine-seeking behavior in rats. Neuroscience 117:477-483. CrossRef Medline

Shaham Y, Shalev U, Lu L, De Wit H, Stewart J (2003) The reinstatement model of drug relapse: history, methodology and major findings. Psychopharmacology (Berl) 168:3-20. CrossRef Medline

Thorn DA, Jing L, Qiu Y, Gancarz-Kausch AM, Galuska CM, Dietz DM, Zhang Y, Li JX (2014) Effects of the trace amine-associated receptor 1 agonist RO5263397 on abuse-related effects of cocaine in rats. Neuropsychopharmacology 39:2309-2316. CrossRef Medline

Thorn DA, Qiu Y, Jia S, Zhang Y, Li JX (2016) Antinociceptive effects of imidazoline I2 receptor agonists in the formalin test in rats. Behav Pharmacol 27:377-383. CrossRef Medline

Venniro M, Caprioli D, Shaham Y (2016) Animal models of drug relapse and craving: from drug priming-induced reinstatement to incubation of craving after voluntary abstinence. Prog Brain Res 224:25-52. CrossRef Medline

Wang X, Luo YX, He YY, Li FQ, Shi HS, Xue LF, Xue YX, Lu L (2010) Nucleus accumbens core mammalian target of rapamycin signaling pathway is critical for cue-induced reinstatement of cocaine seeking in rats. J Neurosci 30:12632-12641. CrossRef Medline

Wang ZJ, Martin JA, Mueller LE, Caccamise A, Werner CT, Neve RL, Gancarz AM, Li JX, Dietz DM (2016) BRG1 in the nucleus accumbens regulates cocaine-seeking behavior. Biol Psychiatry 80:652-660. CrossRef Medline

Wenzel JM, Cotten SW, Dominguez HM, Lane JE, Shelton K, Su ZI, Ettenberg A (2014) Noradrenergic beta-receptor antagonism within the central nucleus of the amygdala or bed nucleus of the stria terminalis attenuates the negative/anxiogenic effects of cocaine. J Neurosci 34:34673474. CrossRef Medline

Wolinsky TD, Swanson CJ, Smith KE, Zhong H, Borowsky B, Seeman P, Branchek T, Gerald CP (2007) The Trace Amine 1 receptor knockout mouse: an animal model with relevance to schizophrenia. Genes Brain Behav 6:628-639. CrossRef Medline

Xie Z, Miller GM (2007) Trace amine-associated receptor 1 is a modulator of the dopamine transporter. J Pharmacol Exp Ther 321:128-136. CrossRef Medline

Xie Z, Miller GM (2009a) Trace amine-associated receptor 1 as a monoaminergic modulator in brain. Biochem Pharmacol 78:1095-1104. CrossRef Medline

Xie Z, Miller GM (2009b) A receptor mechanism for methamphetamine action in dopamine transporter regulation in brain. J Pharmacol Exp Ther 330:316-325. CrossRef Medline

Xie Z, Westmoreland SV, Bahn ME, Chen GL, Yang H, Vallender EJ, Yao WD, Madras BK, Miller GM (2007) Rhesus monkey trace amine-associated receptor 1 signaling: enhancement by monoamine transporters and attenuation by the D2 autoreceptor in vitro. J Pharmacol Exp Ther 321: 116-127. CrossRef Medline

Xie Z, Westmoreland SV, Miller GM (2008) Modulation of monoamine transporters by common biogenic amines via trace amine-associated receptor 1 and monoamine autoreceptors in human embryonic kidney 293 cells and brain synaptosomes. J Pharmacol Exp Ther 325:629-640. CrossRef Medline

Zahm DS, Brog JS (1992) On the significance of subterritories in the "accumbens" part of the rat ventral striatum. Neuroscience 50:751-767. CrossRef Medline 